\title{
Correction to: The impact of cochlear implant microphone settings on the binaural hearing of experienced cochlear implant users with single-sided deafness
}

\author{
Anja Kurz ${ }^{1}$ (D) $\cdot$ Maren Zanzinger ${ }^{1} \cdot$ Rudolf Hagen $^{1} \cdot$ Kristen Rak $^{1}$
}

Published online: 28 January 2021

(c) The Author(s) 2021

\section{Correction to: European Archives of Oto-Rhino-Laryngology https://doi.org/10.1007/s00405-020-06450-5}

In the original publication of the article, under the section Binaural effects, the following sentence "Binaural Squelch With the SONNET, the head shadow effect was $-1.2 \mathrm{~dB}$ (range-5.9-0.6) in natural mode, $0.9 \mathrm{~dB}$ (range - 4.3-6.1), and in adaptive mode, and $-0.4 \mathrm{~dB}$ (range - 4.4-2.5) in the omnidirectional mode" was published incorrectly.

The correct sentence should read as "Binaural Squelch With the SONNET, the binaural squelch effect was $-1.2 \mathrm{~dB}$ (range - 5.9-0.6) in natural mode, $0.9 \mathrm{~dB}$ (range -4.3-6.1), and in adaptive mode, and $-0.4 \mathrm{~dB}$ (range - 4.4-2.5) in the omnidirectional mode."

In addition, there are some mistakes in the paragraph "Binaural Summation". The correct paragraph should read as below,

Binaural Summation With the SONNET, the binaural summation effect was $-0.6 \mathrm{~dB}$ (range $-1.1-2.7$ ) in natural mode, $0.0 \mathrm{~dB}$ (range - 1.3-2.2), and in adaptive mode, and $0.2 \mathrm{~dB}$ (range - 1.2-2.1) in the omnidirectional mode. No significant differences were found between SONNET modes. With the OPUS 2/RONDO, the binaural summation effect was $-0.4 \mathrm{~dB}$ (range - 1.1-1.6). No significant differences were found between SONNET modes and the OPUS 2/RONDO. (see Fig. 2c).

The original article has been updated.

Open Access This article is licensed under a Creative Commons Attribution 4.0 International License, which permits use, sharing, adaptation, distribution and reproduction in any medium or format, as long as you give appropriate credit to the original author(s) and the source, provide a link to the Creative Commons licence, and indicate if changes were made. The images or other third party material in this article are included in the article's Creative Commons licence, unless indicated otherwise in a credit line to the material. If material is not included in the article's Creative Commons licence and your intended use is not permitted by statutory regulation or exceeds the permitted use, you will need to obtain permission directly from the copyright holder. To view a copy of this licence, visit http://creativecommons.org/licenses/by/4.0/.

Publisher's Note Springer Nature remains neutral with regard to jurisdictional claims in published maps and institutional affiliations.
The original article can be found online at https://doi.org/10.1007/ s00405-020-06450-5.

\section{Anja Kurz}

Kurz_A@ukw.de

1 Department of Oto-Rhino-Laryngology, Plastic, Aesthetic and Reconstructive Head and Neck Surgery, Comprehensive Hearing Center, University Hospital Würzburg, Josef Schneider Str. 11, 97080 Würzburg, Germany 